\title{
MORPHOLOGICAL AND GEOLOGICAL CHARACTERISTICS OF TWO DENUDED CAVES IN SW SLOVENIA
}

\section{MORFOLOŠKE IN GEOLOŠKE ZNAČILNOSTI DVEH DENUDIRANIH JAM V JZ SLOVENIJI}

STANKA ŠEBELA ${ }^{1}$

\footnotetext{
${ }^{1}$ Karst Research Institute ZRC SAZU, Titov trg 2, SI-6230 POSTOJNA, SLOVENIA
} 
UDK: 551.44:551.311.24(497.4)

\section{Stanka Šebela: Morfološke in geološke značilnosti dveh denudiranih jam v JZ Sloveniji}

Denudirane ali brezstrope jame lahko velikokrat določimo iz originalne kraške topografije. Za ta članek sem preučila morfologijo in geologijo dveh denudiranih jam. V letu 1994 je bila pri vasi Povir odkrita prva denudirana jama, in sicer ko je gradnja avtoceste Divača-Dane že potekala. Originalno jamsko morfologijo smo lahko določili iz topografskih kart 1:1.000. V letu 1996 pa smo s predhodnimi krasoslovnimi raziskavami še pred začetkom gradnje avtoceste Divača-Kozina določili 4 denudirane jame. Posebno denudirana jama pri kraju Kačiče-Pared je bila morfološko zelo dobro izražena.

Ključne besede: geologija, krasoslovje, denudirane jame, JZ Slovenija.

\section{Abstract}

UDC: 551.44:551.311.24(497.4)

\section{Stanka Šebela: Morphological and Geological Characteristics of two denuded caves in SW Slovenia}

Denuded or unroofed caves can be identified from original karst topography many times. For this article the morphology and geology of 2 denuded caves were studied. In 1994 first denuded cave was discovered near village Povir when the highway construction Divača-Dane was already taking place. Original cave morphology was realized from topographic maps 1:1.000. In 1996 with preliminary karst studies before beginning of highway construction Divača-Kozina 4 denuded caves were discovered. The one near Kačiče-Pared was very well morphologically expressed.

Key words: geology, karstology, denuded caves, SW Slovenia. 


\section{INTRODUCTION}

With highway construction in SW Slovenia many denuded or unroofed caves were discovered before or between highway construction. First one was opened with construction works on the highway Divača-Dane near village Povir.

The other cave which was studied for this article is situated on the highway Divača-Kozina. It was first identified with preliminary karst studies before highway construction begun (Šebela 1996). It was possible to identify that cave as also 3 others from original karst topography.

For both denuded caves geological mapping was carried out. The aim was to determine influence of geological structure for denuded caves formation.

The study was done within the project "The vulnerability map of karst along highways in Slovenia" co-sponsored by Ministry for Sciences and Technology of the Republic of Slovenia and within the project "Karstological control of highway construction in Slovenia" sponsored by DARS and organized within the Zavod za naravno in kulturno dediščino, Nova Gorica (Institute of Protection of Natural and Cultural Heritage, Nova Gorica).

Thanks to Jure Hajna (Karst Research Institute ZRC SAZU) for accomplishing 4 figures for this article done with the computer.

\section{DENUDED CAVE NEAR POVIR ON HIGHWAY DIVAČA-DANE}

During beginning of construction of highways across Kras in Slovenia in 1994 the first socalled denuded or unroofed cave was discovered near Povir on highway Divača-Dane (Knez \& Šebela 1994; Šebela \& Mihevc 1995; Mihevc 1996; Mihevc \& Zupan 1996; Mihevc et al. 1998)). Because of the highway construction detailed topographic maps in 1:1.000 were done. Contour lines on such map are determined on $1 \mathrm{~m}$ and sometimes also on $0,5 \mathrm{~m}$. On the map obvious morphologic depression is shown. It runs from altitudes of 395,3-401m (Fig. 1). General direction of the denuded cave is NW-SE. It runs between cross sections 681-701 (Fig. 2) on the highway. When the cave was already empty because they removed cave sediments we measured the ground plan of the cave. It's $320 \mathrm{~m}$ long and up to $10 \mathrm{~m}$ wide passage.

In the NW part of denuded cave a morphological depression exist as a not very typical shape of doline. Towards SE there is about $40 \mathrm{~m}$ of the cave passage with the roof. Than we have first about $40 \mathrm{~m}$ of unroofed passage which continues into the doline (bottom on 395,9 m). The doline was $10 \mathrm{~m}$ deep with $40 \mathrm{~m}$ of diameter. From the doline towards SE there is unroofed passage which runs out from the highway and continues through the doline south from the highway.

During highway construction all cave sediments were not removed from the passage, so we don't know for sure what was the deepest point of the cave passage. But regarding the results of the drilling (cross section 691) the thickness of cave sediments was less than $12 \mathrm{~m}$.

The cave is well visible also on aerial photographs as white zone what represents different vegetation due to thicker sediments. In the south corner of Fig. 1 the cave passage was determined from aerial photographs, even before it was proved on the field. In the cave history both passages probably belonged to the same cave system.

When the denuded cave was opened basic geological investigations were done. Measurements of strike and dip of bedding planes and tectonic structures were accomplished. The cave is developed 


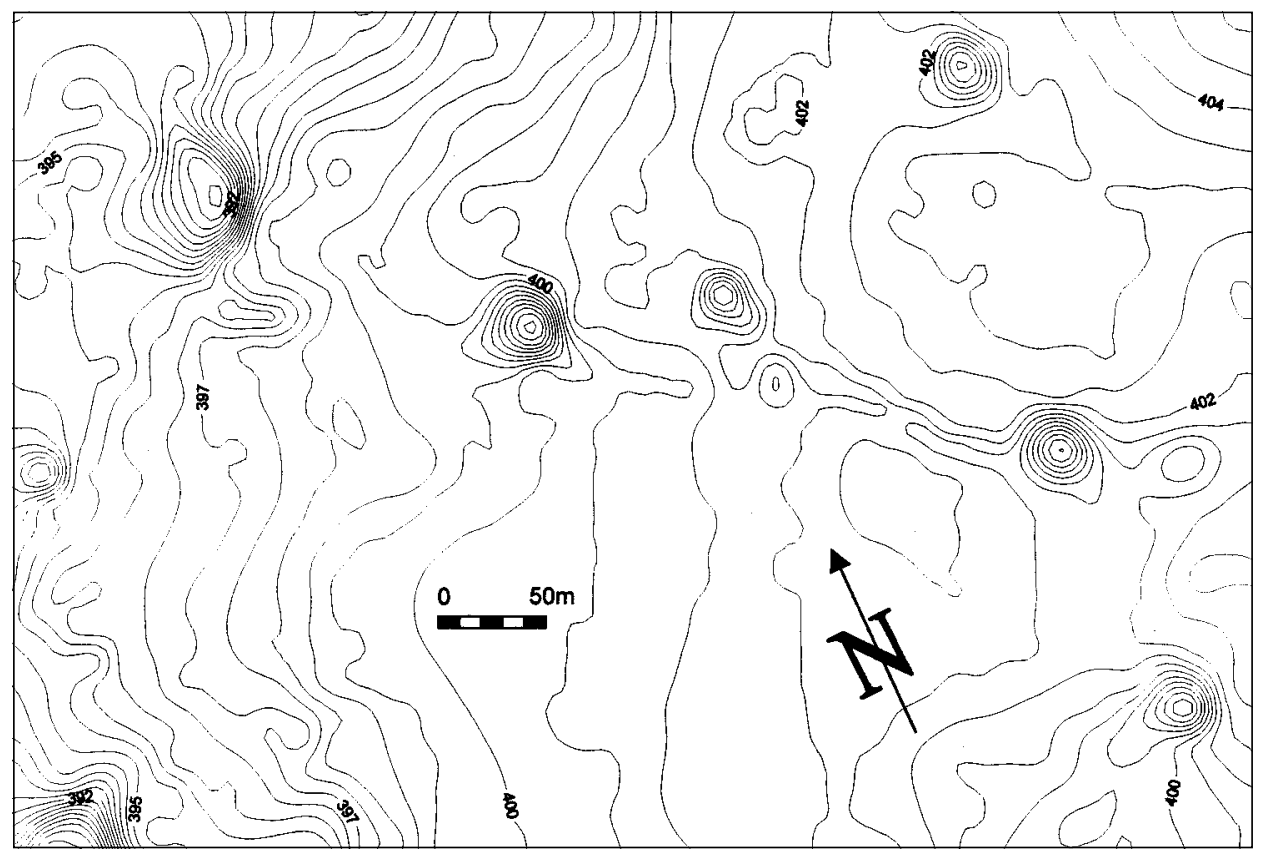

Fig. 1: Original morphology of denuded cave near Povir before construction of highway DivačaDane. Altitudes for contour lines are in meters.

Sl. 1: Originalna morfologija denudirane jame pri Povirju pred gradnjo avtoceste Divača-Dane. Nadmorske višine izohips so v metrih.

in Liburnian formation (K-Pc). It's bedded and contains platy limestone, marly limestone and limestone breccia (Jurkovšek et al. 1996).

In NW part of the cave the limestone dips towards $\mathrm{S}$ for $20^{\circ}$, in central and SE part limestone dips towards $\mathrm{SW}$ for $20-30^{\circ}$ (Fig. 2). The thickness of the limestone beds is $0,2-0,4 \mathrm{~m}$. According to geological map of Jurkovšek et al. (1996) between denuded cave and Divača fault a syncline is situated in general direction NW-SE. It dies out just in the area between the cave and Divača fault (Fig. 3). According to geological measurements in the cave we can confirm that idea.

The denuded cave near Povir is situated about $200 \mathrm{~m}$ north from Divača fault (NW-SE direction). In the cave the fault $50 / 70-90^{\circ}$ is well expressed from central to E part of the cave. We can also follow the fractured zones $70 / 80^{\circ}, 150^{\circ}$ and $140^{\circ}$. In the western doline fractured zones $70 / 30^{\circ}, 70^{\circ}$, $60^{\circ}$ and $340 / 80^{\circ}$ are present.

The cave passage is mostly developed according to direction of bedding planes.

Divača fault which crosses the highway about $1 \mathrm{~km} \mathrm{NW}$ from denuded cave near Povir has the characteristics of horizontal movements (sinistral and dextral) and vertical movements (NE block of the fault rose and SW sank). According to geological map of Jurkovšek et al. (1996) Divača fault 


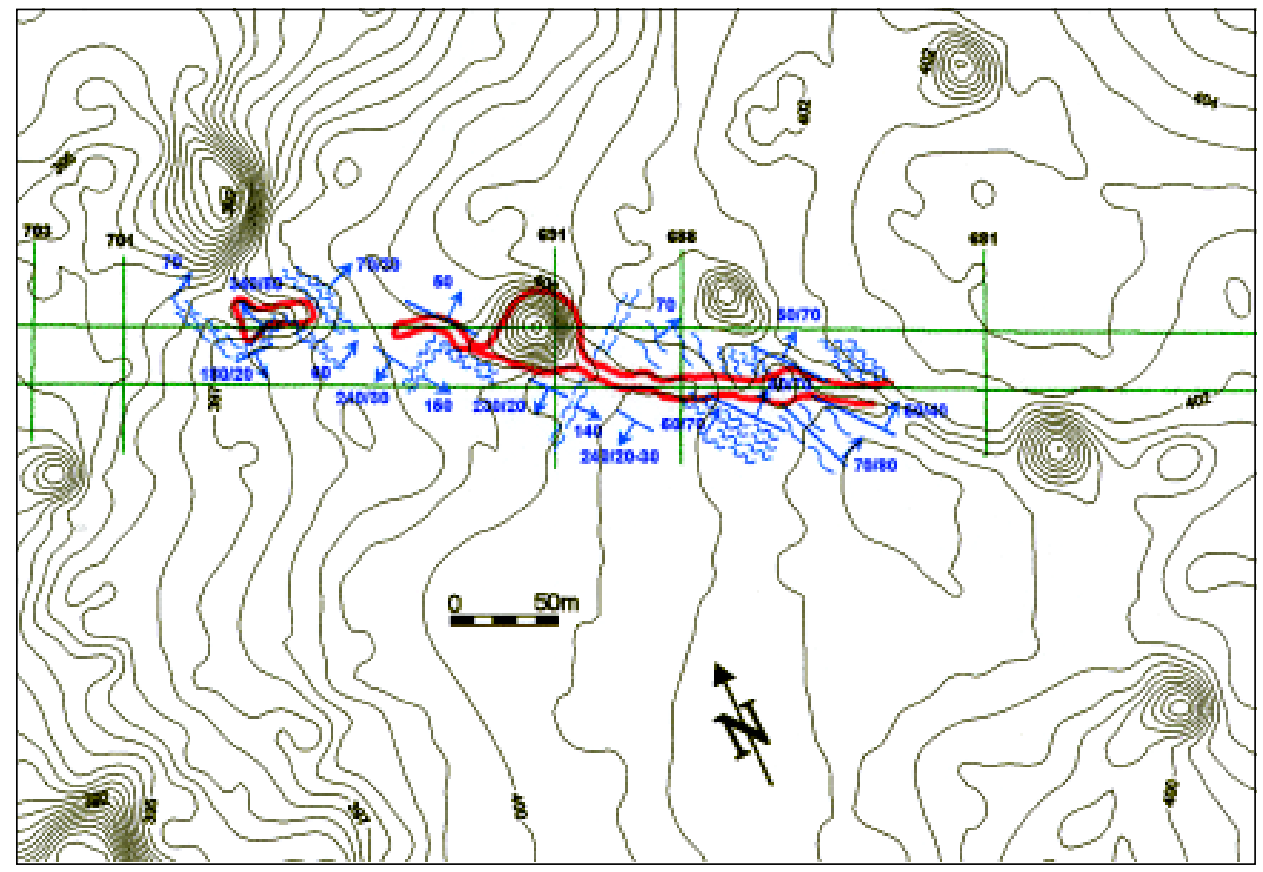

Fig. 2: Geological map of denuded cave near Povir.

1-denuded cave, 2-denuded cave determined from aerial photographs, 3-strike and dip of limestone bedding planes, 4-fault, 5-fissured zone, 6-broken zone.

Sl. 2: Geološka karta denudirane jame pri Povirju.

1-denudirana jama, 2-denudirana jama določena iz letalskih posnetkov, 3-smer in vpad plasti apnenca, 4-prelom, 5-razpoklinska cona, 6-porušena cona.

has the characteristics of vertical movement (NE block sank and SW rose) near Divača and Dane. We can conclude that the Dinaric oriented fault suffered more tectonic phases with vertical and horizontal movements. In general sense in last tectonic phase the Divača fault has characteristics of horizontal dextral movements what is also typical for Dinaric oriented faults in SW Slovenia.

The principal structures that formed during the Cretaceous-Paleogene compression are known in literature as Dinaric structures. These are regional folds of NW-SE direction and reverse faults of the same direction that were formed during collision of the Adriatic microplate with the European plate. Deformation during Neogene and Quaternary are associated with the regional compression of the general N-S direction. Dinaric faults have been presumably active in the sense of horizontal displacement since the end of Paleogene to present (Jurkovšek et al. 1996). 


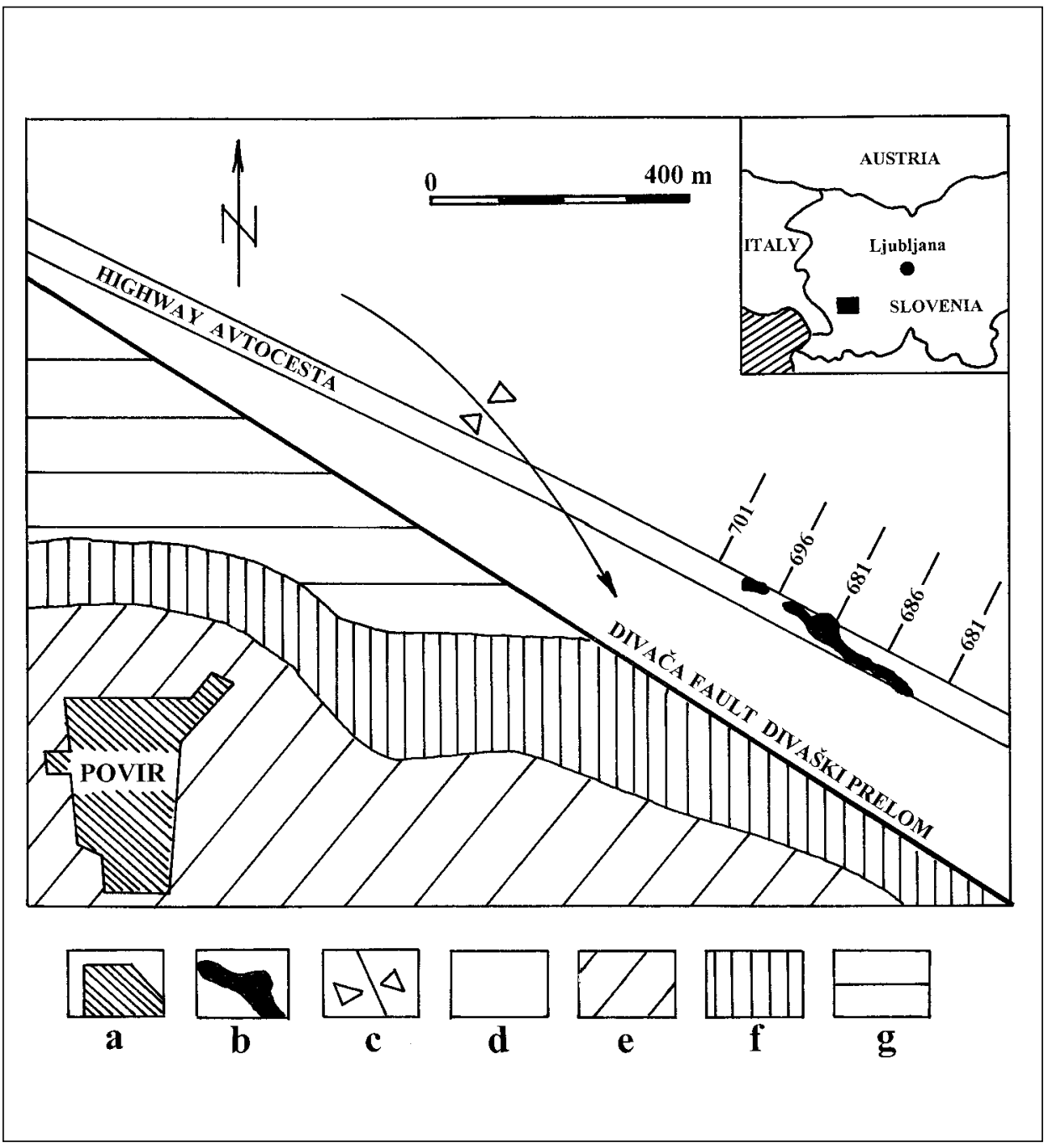

Fig. 3: Geological map of wider area around denuded cave near Povir.

$a$-village, $b$-denuded cave, $c$-syncline, $d$-Liburnian Formation $(K-P c)$, Bedded and platy limestone, marly limestone and limestone breccia, e-Bituminous granular dolomite, Povir Formation $\left(K_{1,2}\right)$, $f$-dolomitic breccia, Povir Formation $\left(K_{1,2}\right)$, g-alteration of limestone, dolomite, limestone and dolomitic breccias, Povir Formation $\left(K_{1,2}\right)$.

Sl. 3: Geološka karta širšega področja denudirane jame pri Povirju.

a-vas, b-denudirana jama, c-sinklinala, d-Liburnijska formacija (K-Pc), plastoviti in ploščasti apnenec, laporni apnenec in apnenčeva breča, e-bituminozni zrnati dolomit, Povirska formacija $\left(K_{1,2}\right)$, f-dolomitna breča, Povirska formacija $\left(K_{1,2}\right)$, g-menjavanje apnenca, dolomita, apnenčeve in dolomitne breče, Povirska formacija $\left(K_{1,2}\right)$. 


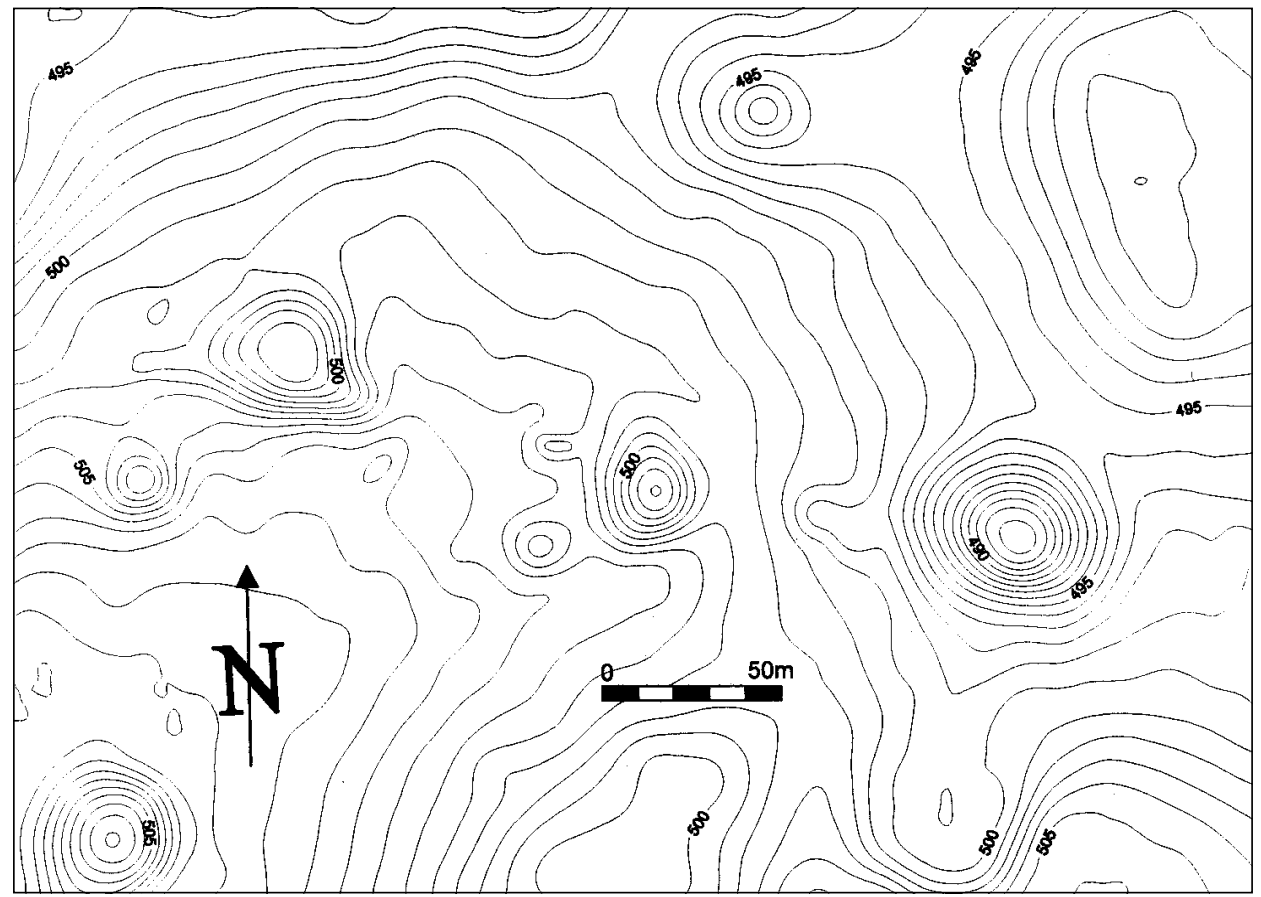

Fig. 4: Original morphology of denuded cave near Kačiče-Pared before construction of highway Divača-Kozina. Altitudes for contour lines are in meters.

Sl. 4: Originalna morfologija denudirane jame pri kraju Kačiče-Pared pred gradnjo avtoceste Divača-Kozina. Nadmorske višine izohips so v metrih.

\section{DENUDED CAVE ON HIGHWAY DIVAČA-KOZINA}

With preliminary investigations before highway construction Divača-Kozina 4 denuded caves were determined (Šebela 1996), with highway construction 2 more denuded caves were found.

The cave between cross section 139 and 149 on the highway was very good morphologically expressed even before highway construction (Fig. 4). All together about $80 \mathrm{~m}$ of the cave passage was determined. General direction of the cave is E-W to NW-SE. In the W part unroofed cave was morphologically deepened for $0,5-1 \mathrm{~m}$ in original topography. After about $30 \mathrm{~m}$ cave passage was lost in the doline (bottom of the doline 497,2 m) which was probably former cave chamber. The continuation of the cave towards $E$ is not well determined. We think that the cave has still the roof in that part. The unroofed cave was possible to follow about $20 \mathrm{~m}$ E from the old road DivačaKozina what is also well seen from the morphology on the topographic map (1:1.000).

The cave is situated between 497,2-505 m a.s.l. It's filled with cave sediments. In $80 \mathrm{~m}$ long cave passage about $20 \mathrm{~m}$ still has the roof. 

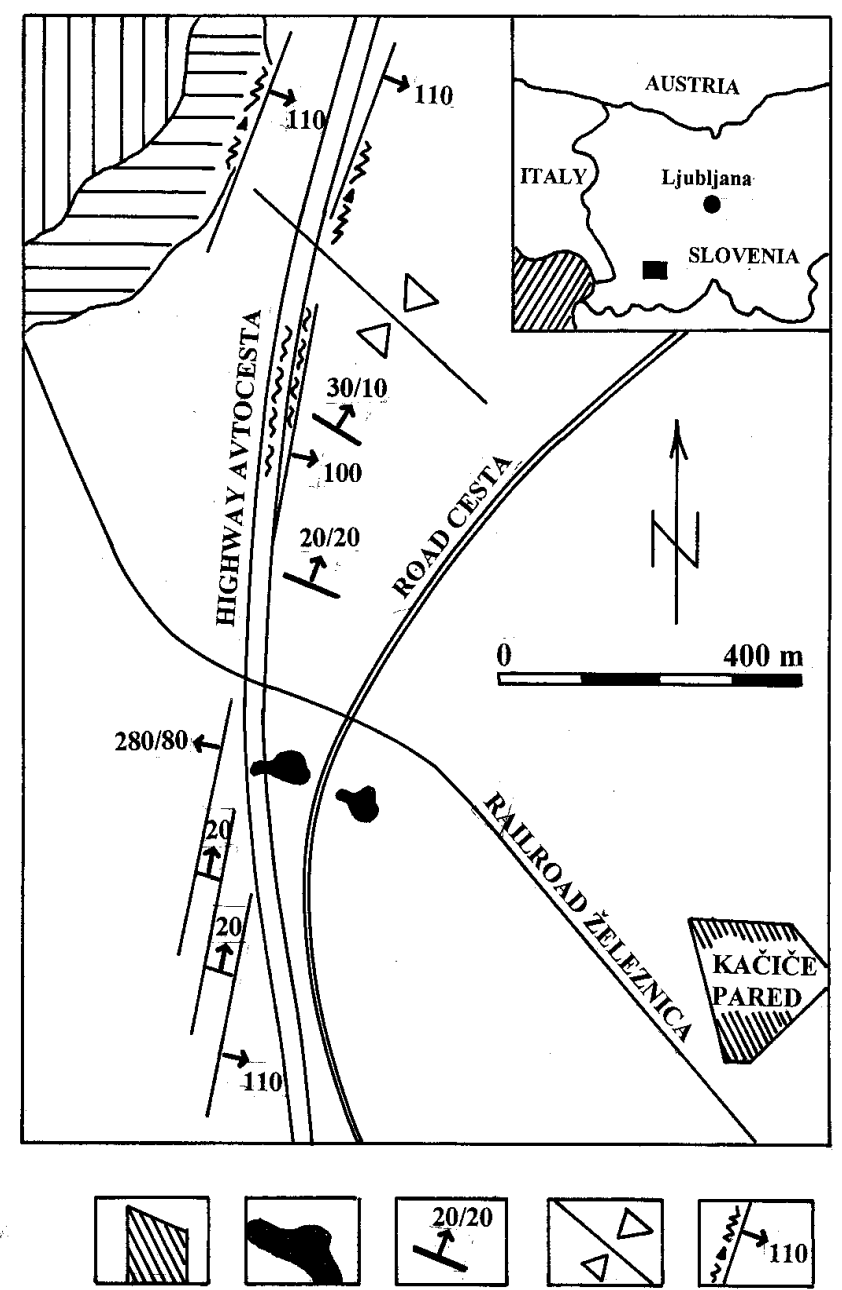

a

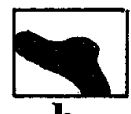

b
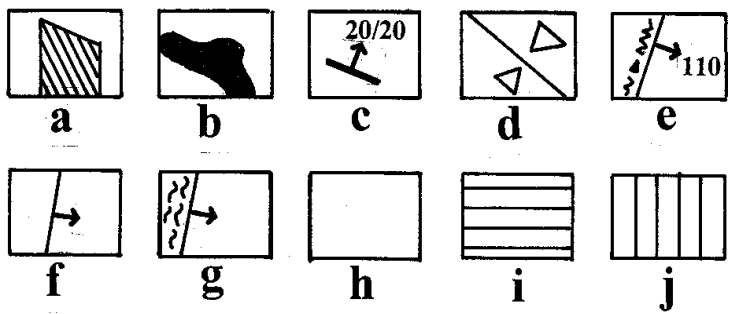

Fig. 5: Geological map of wider area around denuded cave near Kačičce-Pared. $a$-town, $b$-denuded cave, $c$-strike and dip of bedding planes, $d$-syncline, e-fault zone, $f$-fault, g-broken zone, h-alveolinid-numulitid limestone, Eocene, $i$-operculina limestone, Eocene, j-Slivje limestone, Upper Paleocene.

Sl. 5: Geološka karta širšega terena denudirane jame pri kraju Kačiče-Pared. področja denudirane jame pri Povirju.

a-kraj, b-denudirana jama, c-smer in vpad plasti apnenca, $d$-sinklinala, e-prelomna cona, f-prelom, g-porušena cona, h-alveolinsko-numulitni apnenec, Eocen, i-operkulinski apnenec, Eocen, j-Slivski apnenec, Zg. Paleocen. 


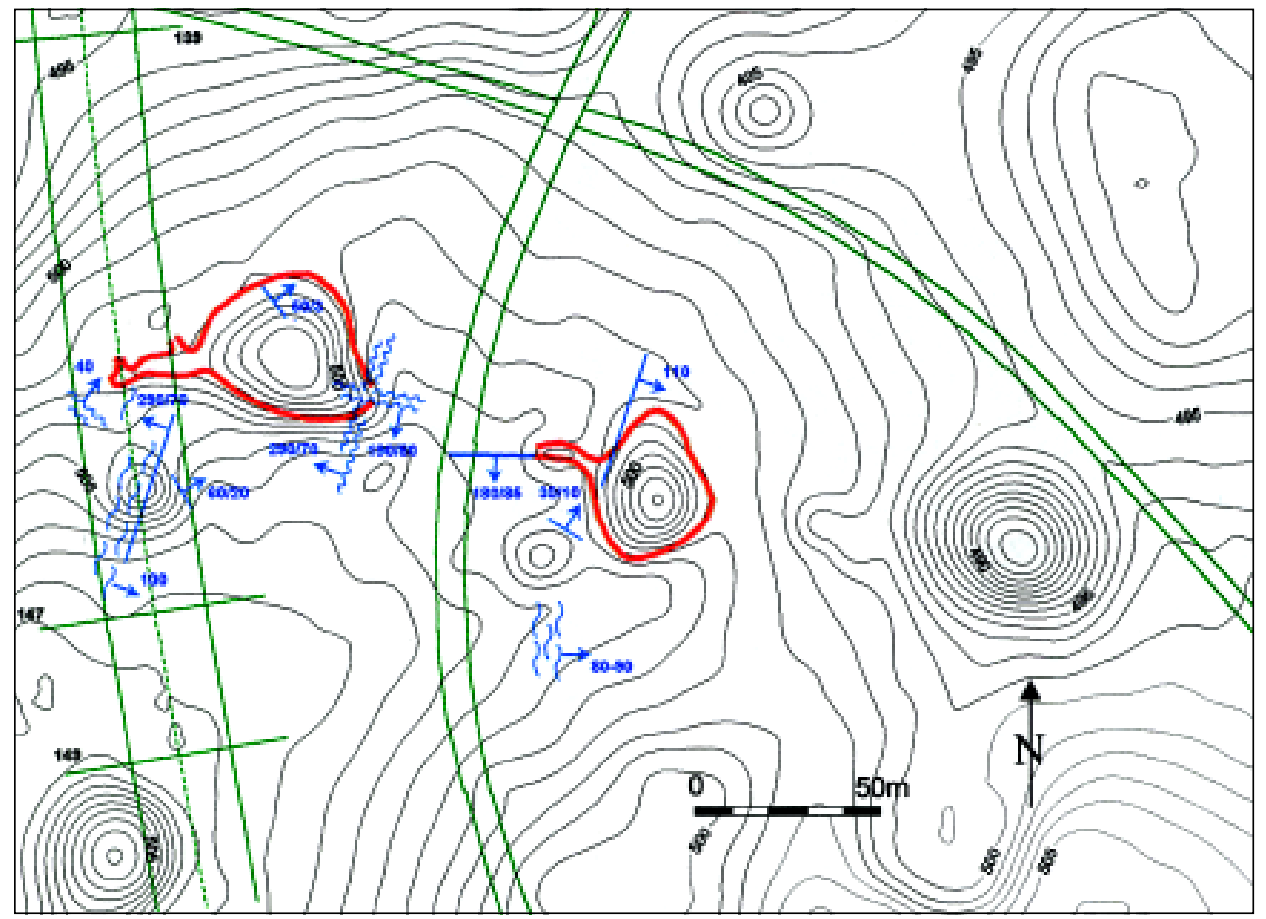

Fig. 6: Geological map of denuded cave near Kačiče-Pared.

1-denuded cave, 2-strike and dip of limestone bedding planes, 3-fault, 4-fissured zone, 5-broken zone.

Sl. 6: Geološka karta denudirane jame pri kraju Kačiče-Pared.

1-denudirana jama, 2-smer in vpad plasti apnenca, 3-prelom, 4-razpoklinska cona, 5-porušena cona.

The cave is developed in Eocene limestone (Jurkovšek et al. 1997) in SW part of the syncline which runs in Dinaric direction (NW-SE) North from Kačiče-Pared (Fig. 5). Alveolinid-numulitid limestone dips towards NE for 10-30 (Fig. 6). It's bedded; locally limestone with chert and limestone with lithothamnians, corals and hydrozoans (Jurkovšek et al. 1996). The direction of the principal fissured to broken zones is $290 / 70^{\circ}$ or $110^{\circ}$ (Fig. 6). The fissures in the direction $40^{\circ}$ and $190 / 80^{\circ}$ are also present. 


\section{DISCUSSION}

According to U/Th datations (Mihevc 1998) and paleomagnetic analyses (Bosak et al. 1998) cave sediments from denuded caves in Slovene Classical Karst are mostly older than 350.000 years and can even be older than 730.000 years. The development and especially dyeing out of such cave systems is obviously connected with tectonic activities in the region and with changes in hydrological conditions. Due to uplifting or lowering of tectonic blocks special regions are more or less influenced by denudation of karst surface. The rate of the dissolution of the karst surface, measured by micrometer during 15 years is $0,02 \mathrm{~mm} /$ year (20 m in 1 million years) (Cucchi et al. 1994).

Tectonic activity of Divača fault from Cretaceous-Paleogene period with later reactivation during Paleogene (Jurkovšek et al. 1996) to the present definitely influenced the development and changes of underground cave systems.

\section{BIBLIOGRAPHY}

Bosak, P., Pruner, P. \& Zupan Hajna, N., 1998: Paleomagnetic Research of Cave sediments in SW Slovenia.- Acta Carsologica SAZU XXVII/2, 151-179, Ljubljana.

Cucchi, F., Forti, F. \& Ulcigrai, F., 1994: Zniževanje površja zaradi korozije.- Acta carsologica SAZU XXIII, 55-62, Ljubljana.

Jurkovšek, B., Toman, M., Ogorelec, B., Šribar, L., Drobne, K., Poljak, M. \& Šribar, L., 1996: Geological Map of the Southern Part of the Trieste-Komen Plateau.- Cretaceous and Paleogene rocks, 1:50.000, 143 pp., Ljubljana.

Jurkovšek, B., Kolar-Jurkovšek, T. \& Ogorelec, B., 1997: Geologija avtocestnega odseka DivačaKozina.- Annales, Anali za istrske in mediteranske študije, 11/'97, series historia naturalis 4, 161-186, Koper.

Knez, M. \& Šebela, S., 1994: Novo odkriti kraški pojavi na trasi avtomobilske ceste pri Divači.Naše jame 36, Ljubljana.

Mihevc, A. 1996: The Cave Brezstropa jama near Povir.- Naše jame 38, 65-75, Ljubljana.

Mihevc, A., 1998: Speleogeneza Matičnega Krasa.-Doktorska disertacija, 150 str., Univerza v Ljubljani, Filozofska fakulteta, Oddelek za geografijo, Ljubljana.

Mihevc, A. \& Zupan, N., 1996: Clastic sediments from dolines and caves on the route of highway at Divača.- Acta Carsologica SAZU XXV, 169-191, Ljubljana.

Mihevc, A., Slabe, T. \& Šebela, S., 1998: Denuded caves - An Inherited element in the Karst Morphology; The Case from Kras.- Acta Carsologica SAZU XXVII/1, 165-174, Ljubljana.

Šebela, S., \& Mihevc, A., 1995: The problems of constructions on karst - The examples from Slovenia.- Karst Geohazards, Proceeding of the Fifth Multidisciplinary conference on Sinkholes and the Engineering and Environmental Impacts of Karst, Gatlinburg/Tennessee/ 2-5 April 1995, 475-479 p., A.A. BALKEMA, Rotterdam.

Šebela, S., 1996: Predhodne krasoslovne raziskave trase avtoceste Divača-Kozina.- Annales 9/96, Anali za istrske in mediteranske študije, series historia naturalis 3, 103-106, Koper. 


\section{MORFOLOŠKE IN GEOLOŠKE ZNAČILNOSTI DVEH DENUDIRANIH JAM V JZ SLOVENIJI}

\section{Povzetek}

V letu 1994 smo pri Povirju na trasi avtoceste Divača-Dane določili prvo tako- imenovano jamo brez stropa ali denudirano jamo (Knez \& Šebela 1994; Šebela \& Mihevc 1995; Mihevc 1996; Mihevc \& Zupan 1996; Mihevc et al. 1998). V kasnejših letih so se ob gradnji avtocest v JZ Sloveniji odkrile številne denudirane jame. Nekatere smo lahko določili že iz originalne kraške morfologije (Šebela 1996). Na denudirane jame lahko sklepamo iz morfoloških značilnosti na detajlnih topografskih kartah (npr. v merilu 1:1.000 ali 1:5.000), iz letalskih posnetkov ter iz predhodnih terenskih ogledov še preden se začne gradnja avtoceste. Najboljšo sliko denudiranih jam pa dobimo ob gradbenih delih na avtocestah, ko odstranijo sedimente iz jam brez stropa.

Za ta članek sem pregledala morfološke in geološke značilnosti dveh primerov denudiranih jam. Prva je bila odkrita na trasi avtoceste Divača-Dane (Knez \& Šebela 1994), druga pa na trasi Divača-Kozina (Šebela 1996). Prvo jamo smo določili, ko so gradbena dela že stekla, drugo pa smo določili iz originalne kraške morfologije pred pričetkom gradbenih del.

Denudirana jama pri Povirju (na trasi Divača-Dane) je $320 \mathrm{~m}$ dolg in do $10 \mathrm{~m}$ širok rov, kjer ponekod lahko še najdemo jamski strop, čeprav prevladuje rov brez stropa. Na topografski karti v merilu 1:1.000, kjer so izohipse na $1 \mathrm{~m}$ ali celo na $0,5 \mathrm{~m}$, je morfologija denudirane jame zelo dobro vidna (slika 1). Na sliki 2 je bil denudiran rov v južnem robu slike določen po opazovanju letalskih posnetkov. Denudirana jama pri Povirju je razvita v liburnijski formaciji, K-Pc (Jurkovšek et al. 1996). Plasti apnenca vpadajo proti jugu in jugozahodu za 20-30 ${ }^{\circ}$. Denudirana jama pri Povirju leži okrog 200 m severno od Divaškega preloma (slika 3).

Na trasi avtoceste Divača-Kozina smo s predhodnimi krasoslovnimi raziskavami določili 4 jame brez stropa (Šebela 1996), kasneje so ob gradnji odkrili še 2 taki jami. Morfološko je bila izredno dobro izražena denudirana jama (slika 4) pri kraju Kačiče-Pared (slika 5). Jama je razvita v alveolinsko-numulitnem apnencu (eocen), ki vpada proti SV za 10-30(slika 6). Glede na regionalno geologijo leži denudirana jama pri kraju Kačiče-Pared v južnem krilu sinklinale (slika 5).

Glede na U/Th analize (Mihevc 1998) in paleomagnetne analize (Bosak et al. 1998) so jamski sedimenti v brezstropih jamah na slovenskem klasičnem krasu večinoma starejši od 350.000 let in celo starejši od 730.000 let. Denudirane jame predstavljajo ostanke nekdanjih aktivnih hidrogeoloških prevodnikov v krasu, ki so zaradi znižanja vodne gladine, tektonske aktivnosti terena ter procesov zniževanja površja zaradi erozije in korozije, danes ostale brez jamskega stropa.

Študija je bila opravljena v okviru projekta "Karta ranljivosti krasa vzdolž avtocest v Sloveniji", ki ga je sofinanciralo Ministrstvo za znanost in tehnologijo RS ter v okviru "Krasoslovnega nadzora pri gradnji avtocest v Sloveniji”, ki ga financira DARS v organizaciji Zavoda za naravno in kulturno dediščino Nova Gorica. 